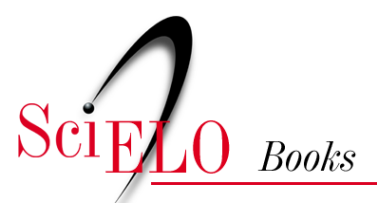

\title{
2 - Estudos médicos na capital do progresso Medical studies in the capital of progress
}

\author{
Simone Petraglia Kropf \\ Aline Lopes de Lacerda \\ Diane Grosklaus Whitty (trad.)
}

\section{SciELO Books / SciELO Livros / SciELO Libros}

KROPF, S.P., and LACERDA, A.L. Estudos médicos na capital do progresso = Medical studies in the capital of progress. In: Carlos Chagas, um cientista do Brasil = Carlos Chagas, scientist of Brazil [online]. Translated by Diane Grosklaus Whitty. Rio de Janeiro: Editora FIOCRUZ, 2009, pp. 42-65. ISBN: 978-65-5708-000-9. https://doi.org/10.7476/9786557080009.0006. \section{International license.}

All the contents of this work, except where otherwise noted, is licensed under a Creative Commons Attribution 4.0

Todo o conteúdo deste trabalho, exceto quando houver ressalva, é publicado sob a licença Creative Commons Atribição 4.0. 


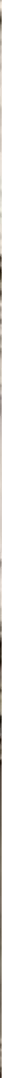

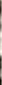

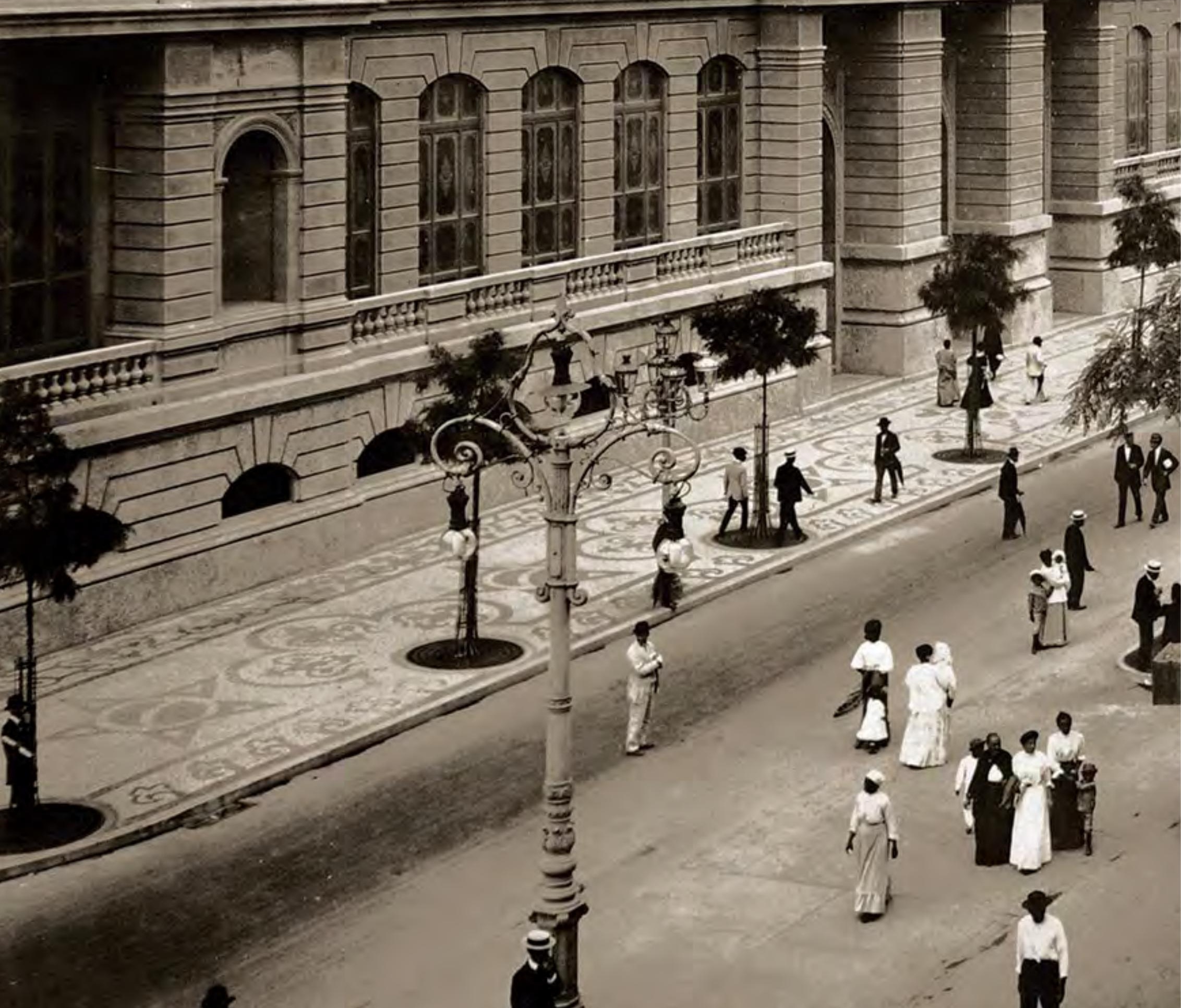


E m abril de 1897, Carlos Chagas matriculou-se na Faculdade de Medicina do Rio de Janeiro. A capital federal vivia dias de grande efervescência. A proximidade do novo século intensificava a crença em um novo tempo, em que o Brasil, guiado pela ciência, se tornaria, enfim, uma nação "civilizada". A "vida vertiginosa" da cidade, para usar a expressão do cronista João do Rio, fazia-se sentir no cotidiano, com a eletricidade, o telégrafo, o telefone e as ferrovias.

O ambiente de renovação ocorria também na Faculdade de Medicina, que buscava acompanhar as teorias de Louis Pasteur (1822-1895) e Robert Koch (1843-1910) sobre a ação dos microorganismos como causas de doenças e dominar os novos recursos, como soros e vacinas, para combatê-las. Desde a década de 1880, vários professores da faculdade defendiam que o ensino médico deveria incorporar os preceitos e práticas da medicina experimental, ou seja, da pesquisa no laboratório visando à produção de novos conhecimentos.

Era um período de proeminência internacional também da chamada medicina tropical. Desde a conquista e exploração de outros continentes, os europeus preocupavam-se com as doenças dos trópicos. Naquela virada de século, a "medicina dos climas quentes" vivia um momento de particular desenvolvimento, com as descobertas sobre o papel dos insetos na transmissão de enfermidades. Em 1898-1899, médicos ingleses e italianos estabeleceram que a malária era transmitida não por "miasmas", mas por mosquitos. Em 1900, os norte-americanos comprovaram o mesmo para a febre amarela. O mundo viveria, a partir de então, uma grande confiança na vitória sobre esses e outros 'males'. Além da teoria do inseto vetor, a preocupação dos europeus em enfrentar as doenças que ocorriam em suas colônias levou à criação, em 1899, na Inglaterra, das primeiras escolas dedicadas ao ensino e ao estudo da medicina tropical. Os conhecimentos e práticas da nova especialidade seriam decisivos na formação e na vida profissional de Chagas.

Dois professores marcaram em especial o seu curso médico, realizado entre 1897 e 1903 . Com Miguel Couto (1865-1934), de quem se tornaria amigo pessoal, aprendeu os métodos e princípios da experimentação, visando ao diagnóstico e ao estudo clínico das doenças que compunham a nosologia brasileira, bem como a concepção de que a clínica médica deveria ser renovada pelos saberes e técnicas propiciados pelo laboratório. Com Francisco Fajardo (1864-1906), pioneiro da microbiologia no Brasil e dos estudos sobre o parasito e o vetor da malária, tomou contato com os temas da medicina tropical. Em seu laboratório, na Santa Casa de Misericórdia, Chagas iniciou-se nas pesquisas sobre essa doença.

Com o objetivo de elaborar sua tese de doutoramento, pré-requisito para a conclusão do curso médico, dirigiu-se em 1902 ao Instituto Soroterápico Federal (também conhecido como Instituto de Manguinhos), criado dois anos antes para fabricar soro e vacina contra a peste bubônica; tendo irrompido em Santos em 1899, a doença ameaçava a capital federal. Oswaldo Gonçalves Cruz (1872-1917), jovem microbiologista treinado no Instituto Pasteur de Paris, havia sido designado para comandar os trabalhos técnicos de Manguinhos. Em fins de 1902, assumiria a direção integral do instituto, que, em 1908, passaria a levar seu nome. Decidido a torná-lo um renomado centro de medicina experimental, Oswaldo Cruz costumava receber estudantes de medicina interessados em desenvolver ali suas pesquisas. Sob sua orientação, Chagas passou a frequentar o Soroterápico diariamente. Em maio de 1903, defendeu sua tese, sobre os aspectos hematológicos da malária.

Apesar do convite feito por Oswaldo Cruz para integrar a equipe de pesquisadores de Manguinhos, optou pela clínica. Em março de 1904, foi nomeado médico da Diretoria-Geral de Saúde Pública e passou a trabalhar no Hospital Paula Cândido, em Jurujuba, Niterói. Ao mesmo tempo, instalou seu consultório particular no centro do Rio, na rua da Assembléia. Naquele mesmo ano casou-se com Iris Lobo, filha do senador mineiro Fernando Lobo Leite Pereira (1851-1918), e que conhecera por intermédio de Miguel Couto. 
$\mathrm{I}^{\mathrm{n}}$ n April 1897, Carlos Chagas entered the Rio de Janeiro School of Medicine. This was a time of cultural effervescence in the federal capital of Rio. The approach of a new century fueled the belief that a new era was dawning, when Brazil, guided by science, would finally become a "civilized" nation. The "dizzying life" of the city, in the words of writer João do Rio, could be felt in the daily march of events, in electric power, the telegraph, the telephone, and the railroad.

This spirit of revitalization was evinced at the School of Medicine as well, where efforts were made to keep step with Louis Pasteur's (1822-1895) and Robert Koch's (1843-1910) theories on the action of microorganisms as disease agents and to master new resources for fighting them, like serums and vaccines. In the 1880s, a number of the school's faculty members had begun arguing that medical teaching should incorporate the precepts and practices of experimental medicine, that is, of laboratory research aimed at producing new knowledge.

It was also the international heyday of so-called tropical medicine. Ever since the Europeans had begun exploring and conquering other continents, they had been worried about the diseases of the tropics. At the turn of the century, "warm-climate medicine" was enjoying a growth spurt, which brought discoveries about the role of insects as disease transmitters. In 1898-1899, British and Italian physicians ascertained that malaria is transmitted not by miasmas but by mosquitoes. In 1900, scientists from the United States proved the same about yellow fever. From that moment on, the world was quite confident in the prospect of victory over these and other illnesses. European concern over the diseases afflicting their colonies led not only to development of the insect vector theory but also to the 1899 creation of the first schools of tropical medicine, in England. Chagas's knowledge of this new specialty and its practices would prove decisive in his training and career.

Two professors were especially influential in Chagas's medical schooling, which extended from 1897 to 1903. One was Miguel Couto (1865-1934), who eventually became his personal friend and who taught him the methods and principles of experimental medicine and their application to the diagnosis and clinical study of Brazilian diseases. Couto further instilled in him the idea that medical practice should be constantly renewed through knowledge and techniques derived from the laboratory. The other teacher was Francisco Fajardo (1864-1906), a pioneer of both microbiology in Brazil and of studies on the malaria parasite and vector, who introduced Chagas to the subjects specific to tropical medicine. Chagas began his investigations of malaria in Fajardo's laboratory at Santa Casa de Misericórdia hospital.

In 1902, Chagas started work on his medical school thesis - a prerequisite for obtaining a degree - at the Federal Serum Therapy Institute. Also known as Manguinhos, the Institute had been established two years earlier to manufacture serum and vaccine against the bubonic plague that had broken out in Santos in 1899 and was threatening the nation's capital. Oswaldo Gonçalves Cruz (1872-1917), a young microbiologist trained at the Pasteur Institute in Paris, had been appointed to oversee technical work at Manguinhos. In late 1902, he was assigned to head the entire Institute, which would come to bear his name in 1908. Determined to mold the Serum Therapy Institute into a respected center of experimental medicine, Oswaldo Cruz welcomed medical students interested in conducting their research there. Under his guidance, Chagas became a daily presence. In May 1903, he defended his medical thesis on hematological aspects of malaria.

Although Oswaldo Cruz invited Chagas to join Manguinhos' research team, he opted instead to take up the practice of medicine. In March 1904, he was appointed to a post as a physician with the General Directorship of Public Health and was assigned to the Paula Cândido Hospital in Jurujuba, Niterói. At the same time, he opened a private practice in downtown Rio, on Assembléia Street. Also in 1904, he married Iris Lobo, daughter of Minas Gerais senator Fernando Lobo Leite Pereira (1851-1918), whom he had met through Miguel Couto. 


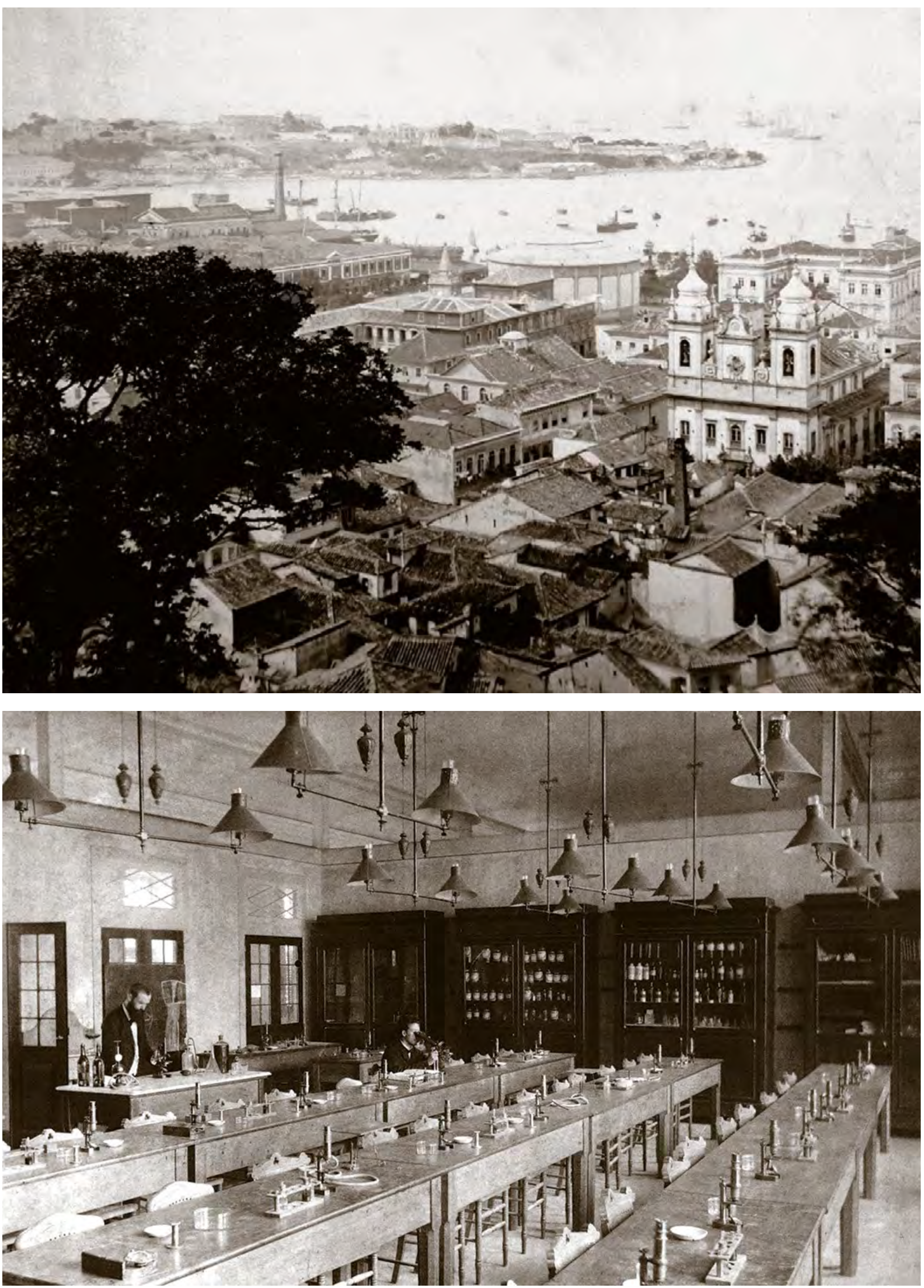


Imagem de abertura - Vista da avenida

Central, vendo-se a Escola de Belas Artes (atual Museu Nacional de Belas Artes). Rio de Janeiro,

c. 1906. Chagas testemunharia a reforma urbana comandada pelo prefeito Francisco Pereira Passos no Rio de Janeiro. A abertura da avenida Central (atual Rio Branco), em 1904-1905, foi o símbolo maior da Belle Époque vivida na capital federal

Foto Augusto Malta

Acervo Museu Histórico Nacional

Opening image - View of Central Avenue, showing the Fine Arts School (now the National Fine Arts Museum). Rio de Janeiro, c. 1906. Chagas would witness Mayor Francisco Pereira Passos's urban reform of Rio de Janeiro. Opened in 1904-1905, Central Avenue (now called Rio Branco) was the premier emblem of the Belle Époque in the nation's capital

Photograph by Augusto Malta

Vista do centro do Rio de Janeiro, tomada do morro do Castelo para a ilha das Cobras, década de 1890. Em destaque, a Igreja de São José; à esquerda, o Paço Imperial

Foto Juan Gutierrez

Acervo Museu Histórico Naciona

View of downtown Rio de Janeiro taken from Morro do Castelo, looking towards Ilha das Cobras, 1890s. São José Church in the foreground, with the Imperial Palace to the left Photograph by Juan Gutierrez

Laboratório para ensino médico, década de 1880

Foto Marc Ferrez

Acervo Fundação Biblioteca Nacional

Medical teaching laboratory, 1880s

Photograph by Marc Ferrez

Recibo de matrícula na Faculdade de Medicina. Rio de Janeiro, 13 abr. 1897 Acervo Casa de Oswaldo Cruz

Enrollment receipt from the School of Medicine. Rio de Janeiro, Apr. 13, 1897

Santa Casa de Misericórdia do Rio de Janeiro, c. 1895 . Situada na antiga praia de Santa Luzia, abrigou, entre 1813 e 1918, o ensino médico na capital

Foto Marc Ferrez

Acervo Instituto Moreira Salles

Santa Casa de Misericórdia Hospital in Rio de Janeiro, c. 1895. Located on former Santa Luzia Beach, the hospital was used for medical $t$ eaching purposes in Rio de Janeiro from 1813 1918

Photograph by Marc Ferrez
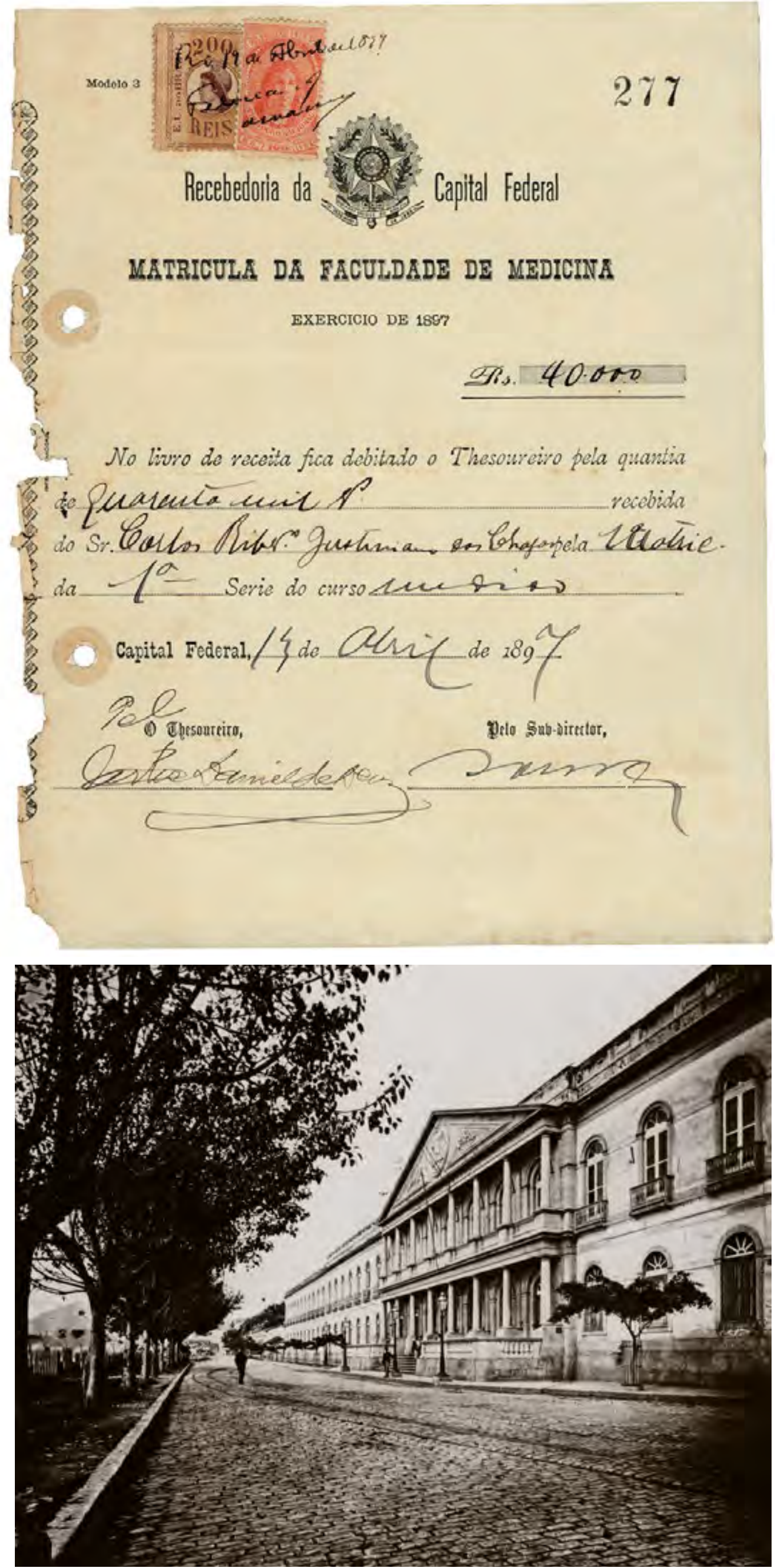

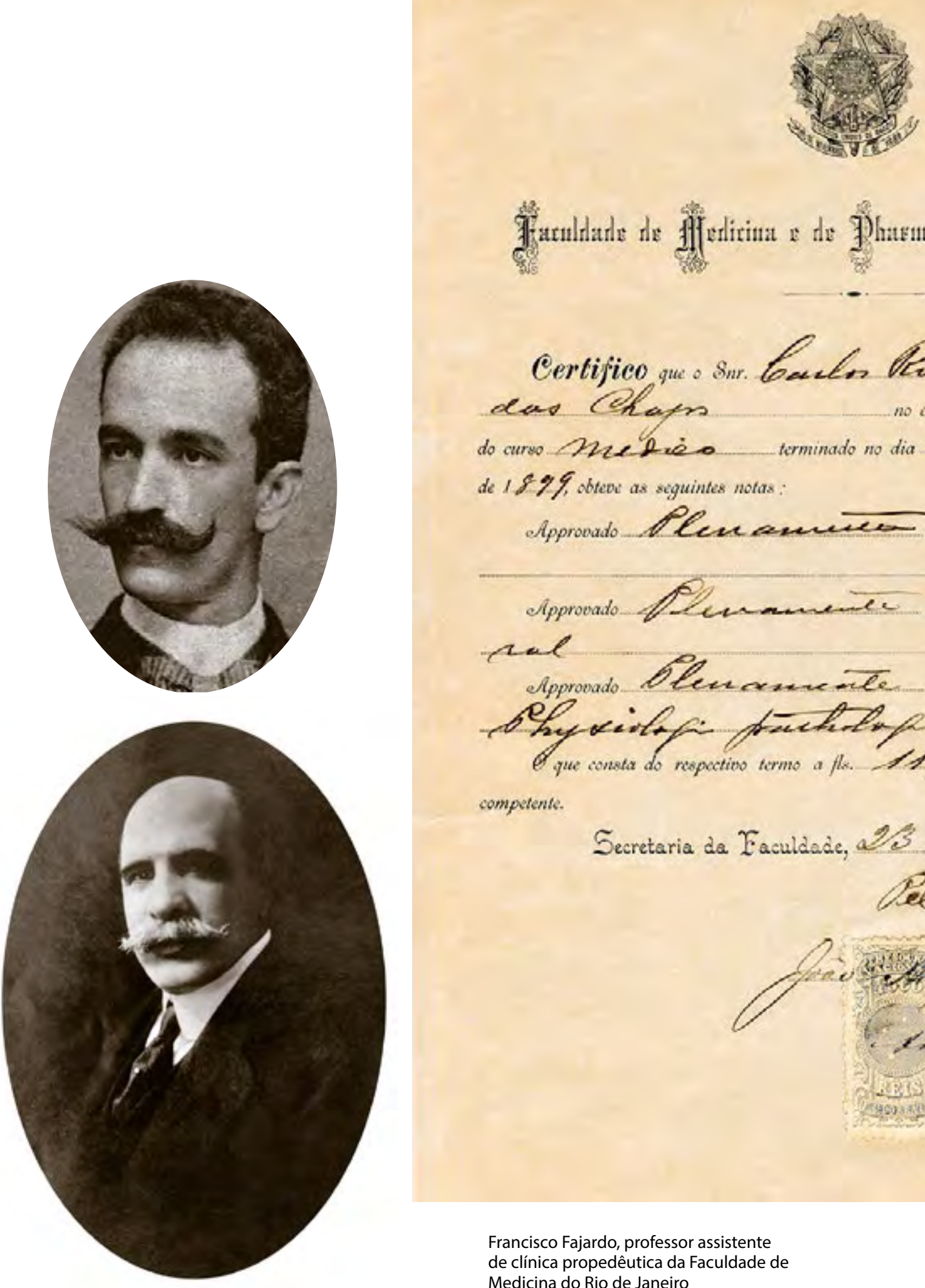

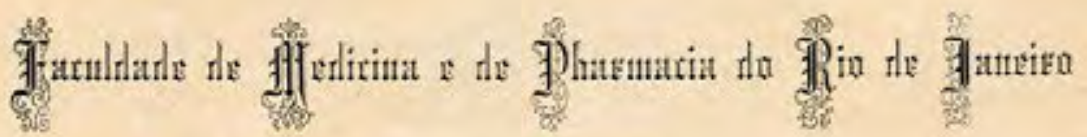

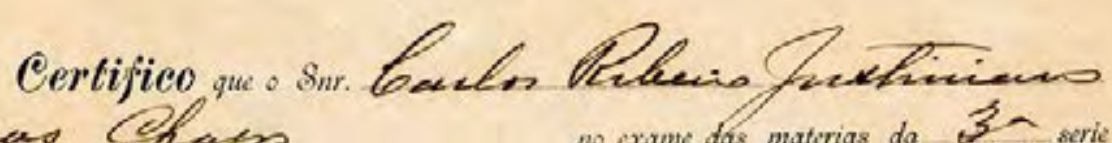
cas Chafos no cxame das matcrias da 3 - serie

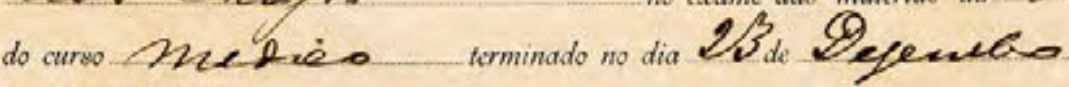
de 1899 , obteve as seguintes notas:

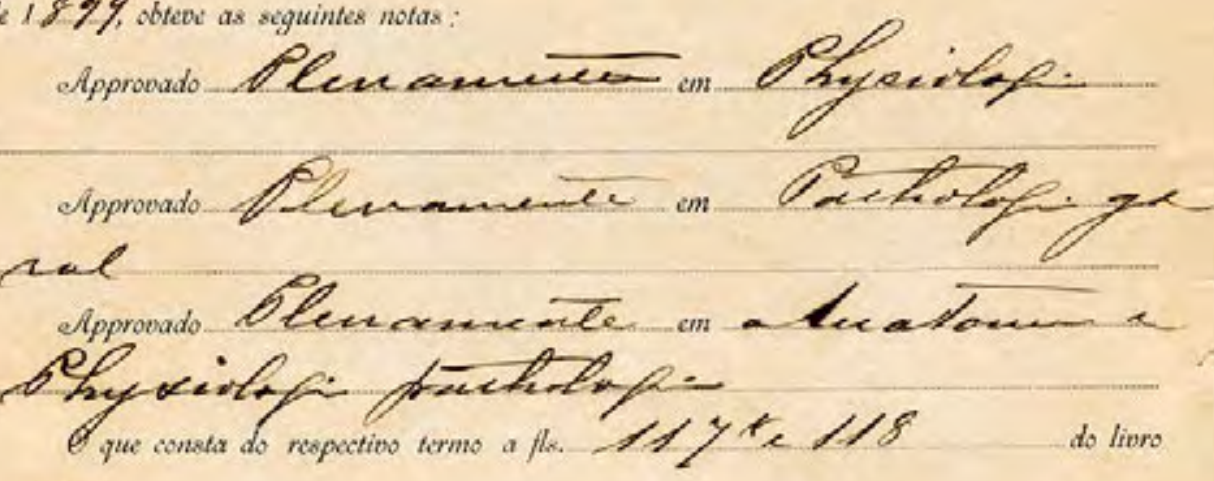
compotente.

$$
\begin{aligned}
& \text { Secretaria da Faculdade, a\% afecerio de } 1 \% 0 \\
& \text { Welo Secretario, }
\end{aligned}
$$

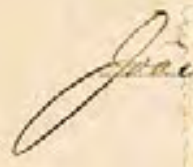

Francisco Fajardo, professor assistente

de clínica propedêutica da Faculdade de Medicina do Rio de Janeiro

Fonte: Benchimol \& Sá, 2005

Francisco Fajardo, assistant professor of

clinical propaedeutics at the Rio de Janeiro

School of Medicine

Miguel Couto, catedrático de clínica médica da Faculdade de Medicina do Rio de Janeiro Acervo Academia Nacional de Medicina

Miguel Couto, chair of clinical practice at the Rio de Janeiro School of Medicine

Certificado de aprovação em disciplinas do curso médico. Rio de Janeiro, 23 maio 1900 Acervo Casa de Oswaldo Cruz

Certificate stating that Chagas passed his third year medical school classes. Rio de Janeiro, May 23, 1900 


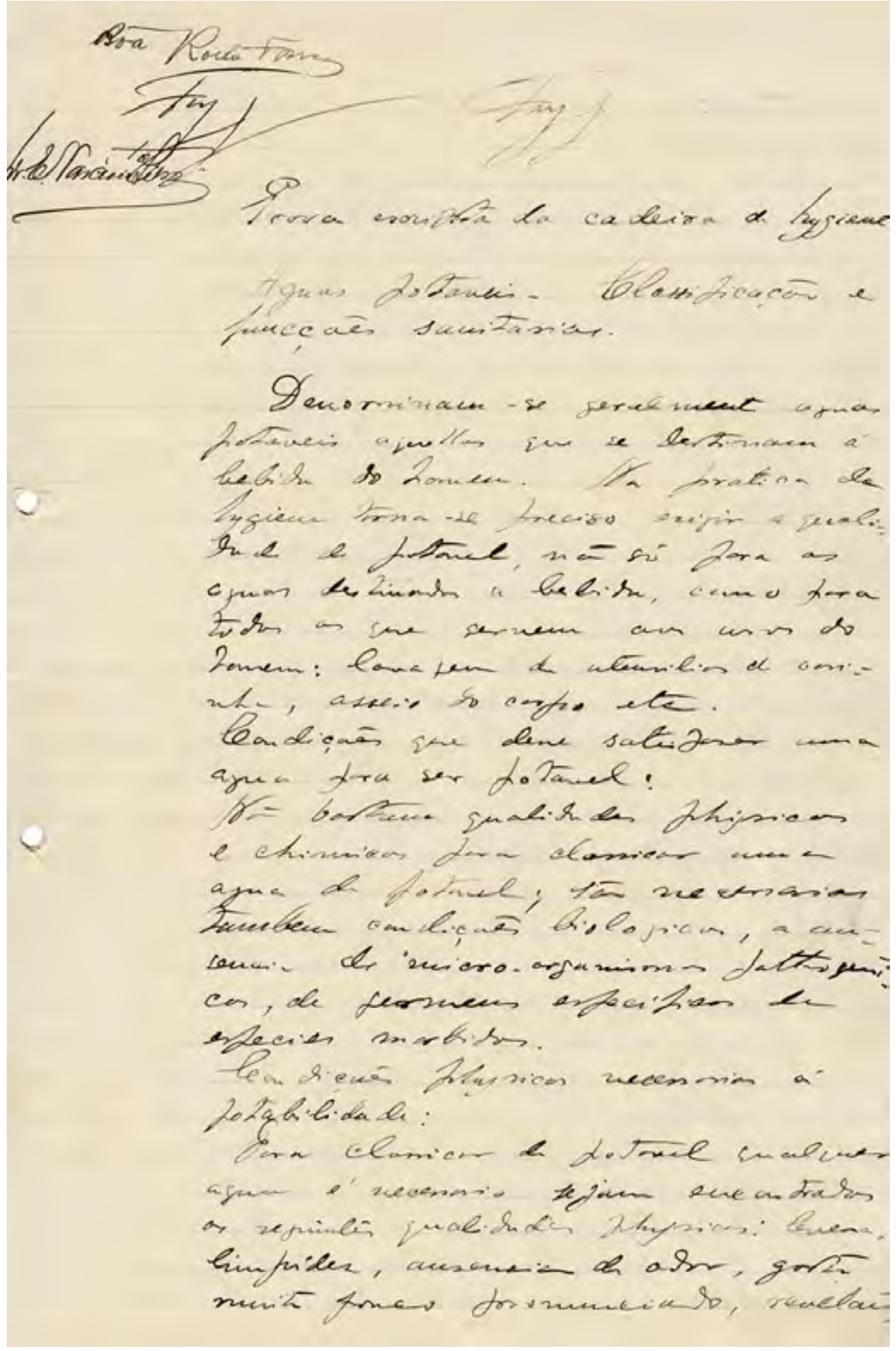

Prova da cadeira de higiene. Rio de Janeiro, 4 dez. 1902

Acervo Casa de Oswaldo Cruz

Hygiene class exam. Rio de Janeiro, Dec. 4, 1902

Oswaldo Cruz, diretor do Instituto

de Manguinhos, aos 29 anos

Acervo Casa de Oswaldo Cruz

Oswaldo Cruz, director of the Manguinhos Institute, at the age of 29

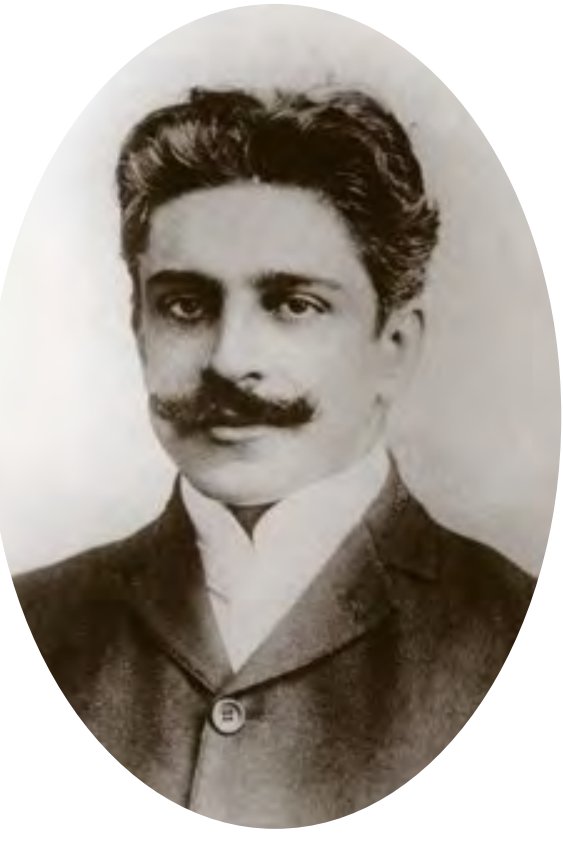

Recebeu-me o querido mestre com a singeleza habitual de suas maneiras e dele ouvi poucas palavras, que apenas expressaram o agrado em acolher aspirações de trabalho, no ambiente de sua incansável atividade. Foi aquele o momento decisivo do meu destino profissional. Do mestre nunca mais eu me afastei e pude apreciar, em 15 anos de amistosa convivência, toda a evolução de seu luminoso espírito.

Carlos Chagas

The esteemed master received me with the simplicity characteristic of his demeanor, and I heard but a few words from him, which simply expressed his pleasure in welcoming someone aspiring to engage in work, within the arena of his tireless activity. This was the decisive moment in my professional destiny. From that point on, I never left my master, and during our fifteen years of congenial fellowship, I had the opportunity to bear witness to the whole evolution of his luminous spirit.

Carlos Chagas 
Sentiam todos que em

Manguinhos cultivava-se a ciência em moldes até então desconhecidos em nosso ambiente e, por esse motivo, não é para surpreender que novos elementos dotados de interesse e curiosidade científica fossem, irresistivelmente, sendo atraídos para aquele modesto laboratório distante e de difícil acesso, no qual Oswaldo Cruz imprimia, em grande estilo, novos rumos à ciência experimental, no Brasil (...). Começou então a estabelecer-se verdadeira romaria de médicos, professores, e de simples estudantes que vinham a Manguinhos à procura do Mestre, desejosos de fazerem sua iniciação científica ou elaborar teses de doutoramento.

Henrique Aragão

Everyone felt that science as cultivated at Manguinhos fit molds wholly novel to our environment, and thus it is no surprise that new individuals displaying scientific interest and curiosity were irresistibly drawn to that modest laboratory, far off and hard to reach, where in grand style Oswaldo Cruz pushed experimental science in Brazil in new directions (...). This set in motion a veritable pilgrimage of physicians, teachers, and ordinary students, who came to Manguinhos seeking the Master, wanting to learn how to do scientific research or write their medical theses.

Henrique Aragão

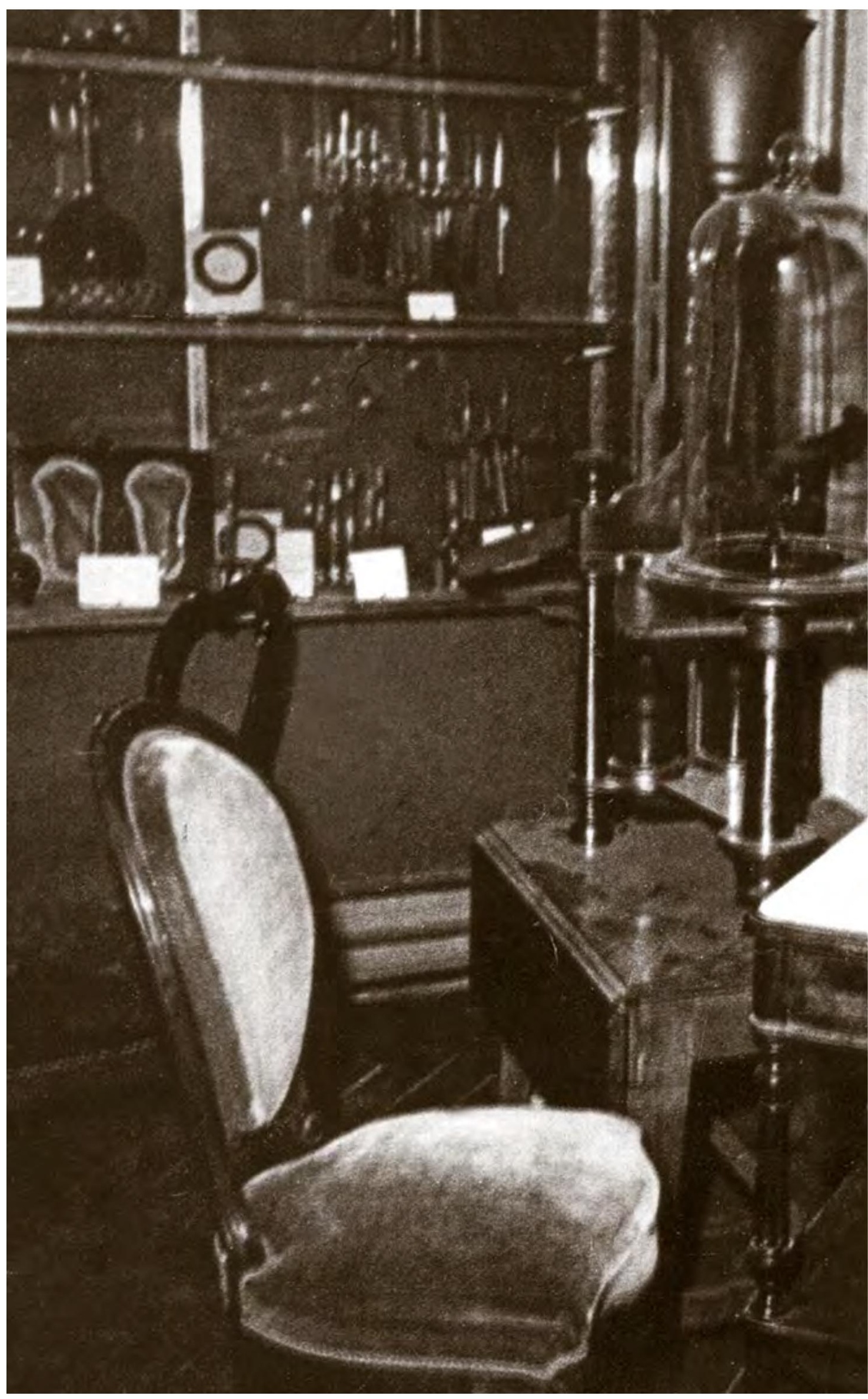

Laboratório do Instituto de

Manguinhos em seus primeiros anos Acervo Casa de Oswaldo Cruz

The Manguinhos Institute laboratory in its early years 
Cais original que servia ao Instituto de Manguinhos. Na época, a baía de Guanabara estendia-se até a região onde posteriormente seria

construída a avenida Brasil. Além do acesso marítimo, o transporte até o local podia ser feito pela Estrada de Ferro Leopoldina, até a parada do Amorim (posteriormente denominada Carlos Chagas, atual estação de Manguinhos) Acervo Casa de Oswaldo Cruz Original pier serving the Manguinhos Institute. At that time, Guanabara Bay stretched back into the area where the metropolitan artery known as Avenida Brasil was later built. In addition to this sea access, the Institute could also be reached by taking the Leopoldina Railroad to Amorim, a stop later renamed Carlos Chagas and now known as Manguinhos

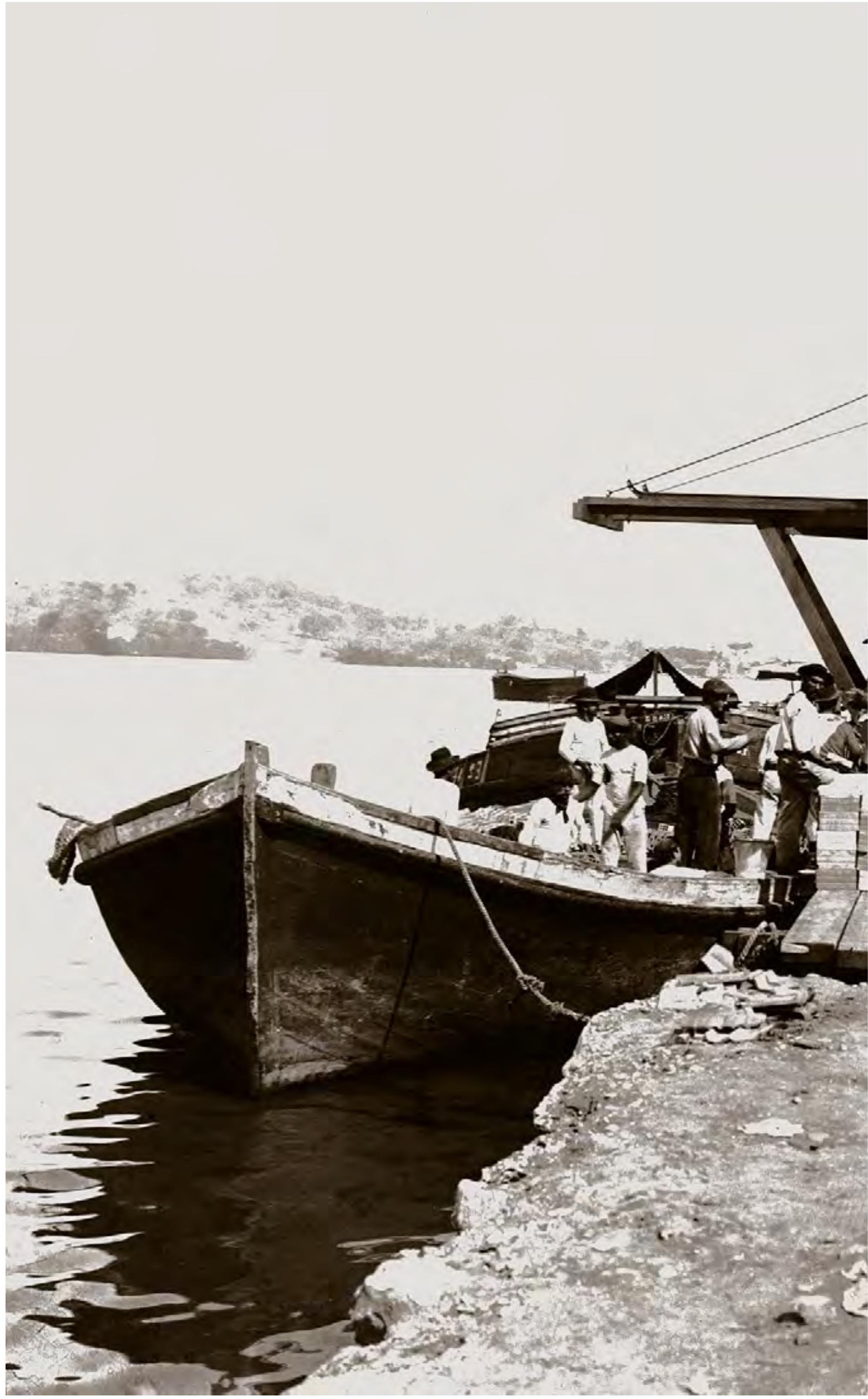




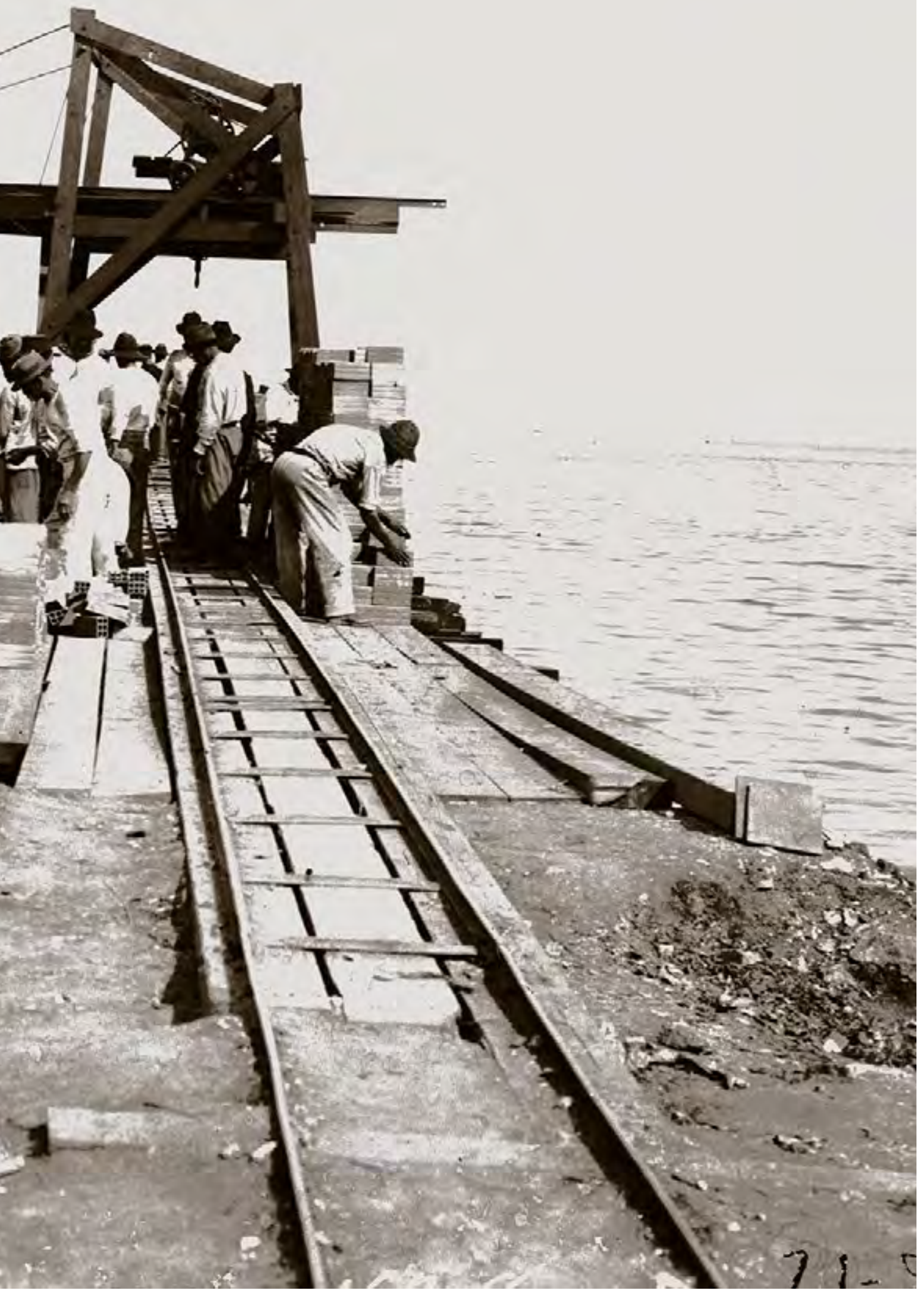

Diariamente tomava-se o trem das 10:30 hs na praça da República, o qual em 20 minutos ia até 'São Francisco Xavier', (...) cujo comboio suburbano ia em 10 minutos à parada do 'Amorim'. Aí esperavam os médicos um servente com 2 cavalos de sela; para estudantes não havia condução.

Ezequiel Dias

Every day one would catch the 10:30 morning train at Praça da República, arriving at São Francisco Xavier in 20 minutes, (...) where the train to the outskirts would reach the Amorim stop in 10 minutes. There the doctors would wait for an attendant with two saddled horses; there was no transportation for students.

Ezequiel Dias 
Nada se podia conceber de mais simples e modesto, mas ali havia o que era absolutamente essencial a qualquer organização científica: um cérebro capaz de dar orientação segura todo voltado para um nobre ideal e um grande entusiasmo de todos pelo trabalho e pelas investigações científicas.

Henrique Aragão

One could imagine nothing simpler nor humbler, yet that which is absolutely vital to any scientific organization was found there: a mind capable of providing sound guidance, thoroughly focused on a noble ideal, and tremendous enthusiasm for work and scientific research on everyone's part.

Henrique Aragão

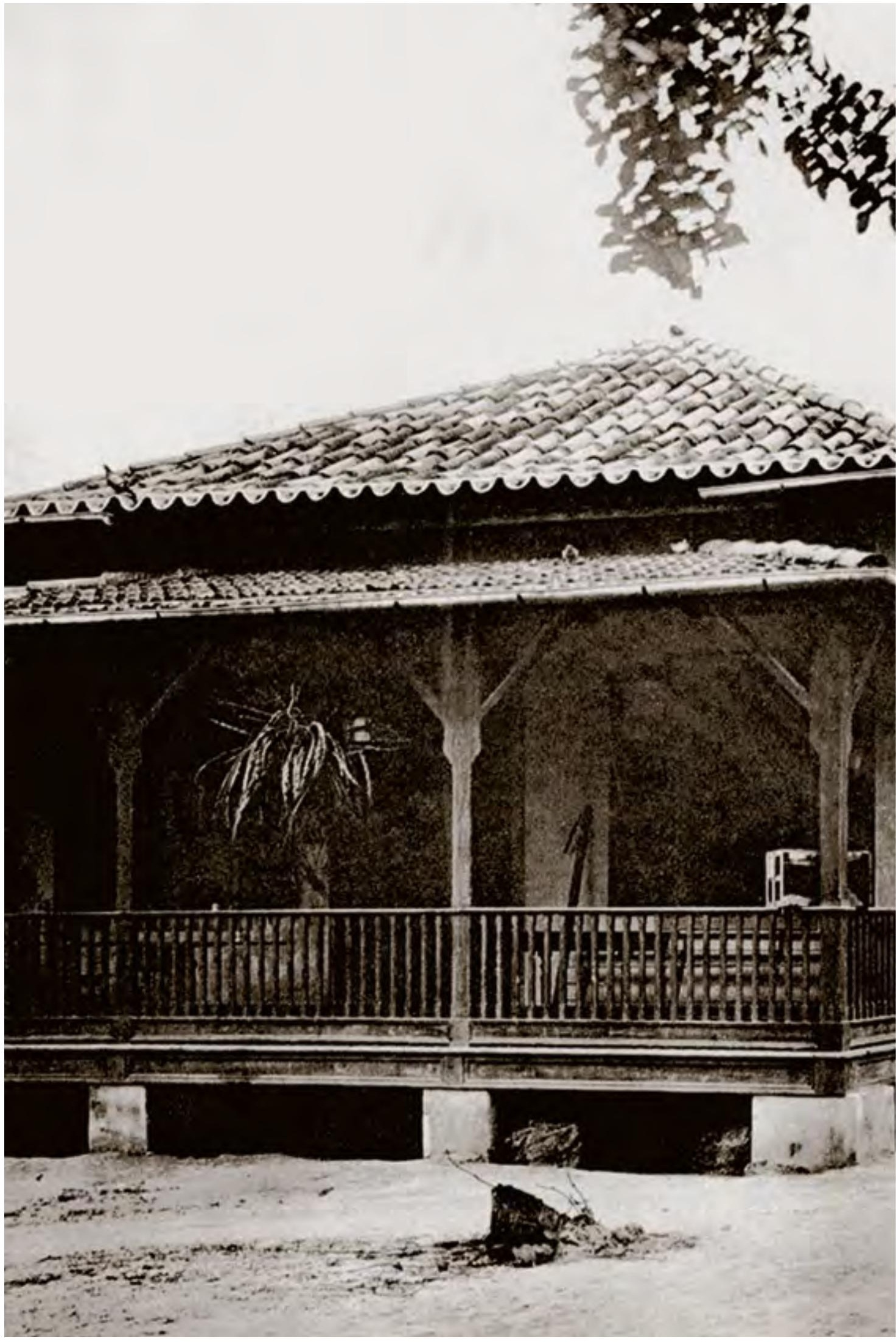

Construção principal da antiga fazenda de Manguinhos, adaptada para o funcionamento dos laboratórios do Instituto Soroterápico Federal nos primeiros anos (1900-1904). Na varanda, havia uma mesa para refeição dos funcionários. A casa branca ao lado abrigava duas salas para laboratórios e uma saleta de lavagem e de esterilização entre elas. O castelo mourisco da atual Fundação Oswaldo Cruz seria construído nesse local a partir de 1905 Acervo Casa de Oswaldo Cruz

Main building on the Manguinhos farm, adapted to house the Federal Serum Therapy Institute's first laboratories (1900-1904). The staff had a dining table on the verandah. Inside the nearby white house were two laboratory rooms, with a smaller room in between them for washing and sterilization. Construction of the Moorish-style castle at today's Oswaldo Cruz Foundation would begin on this spot in 1905 

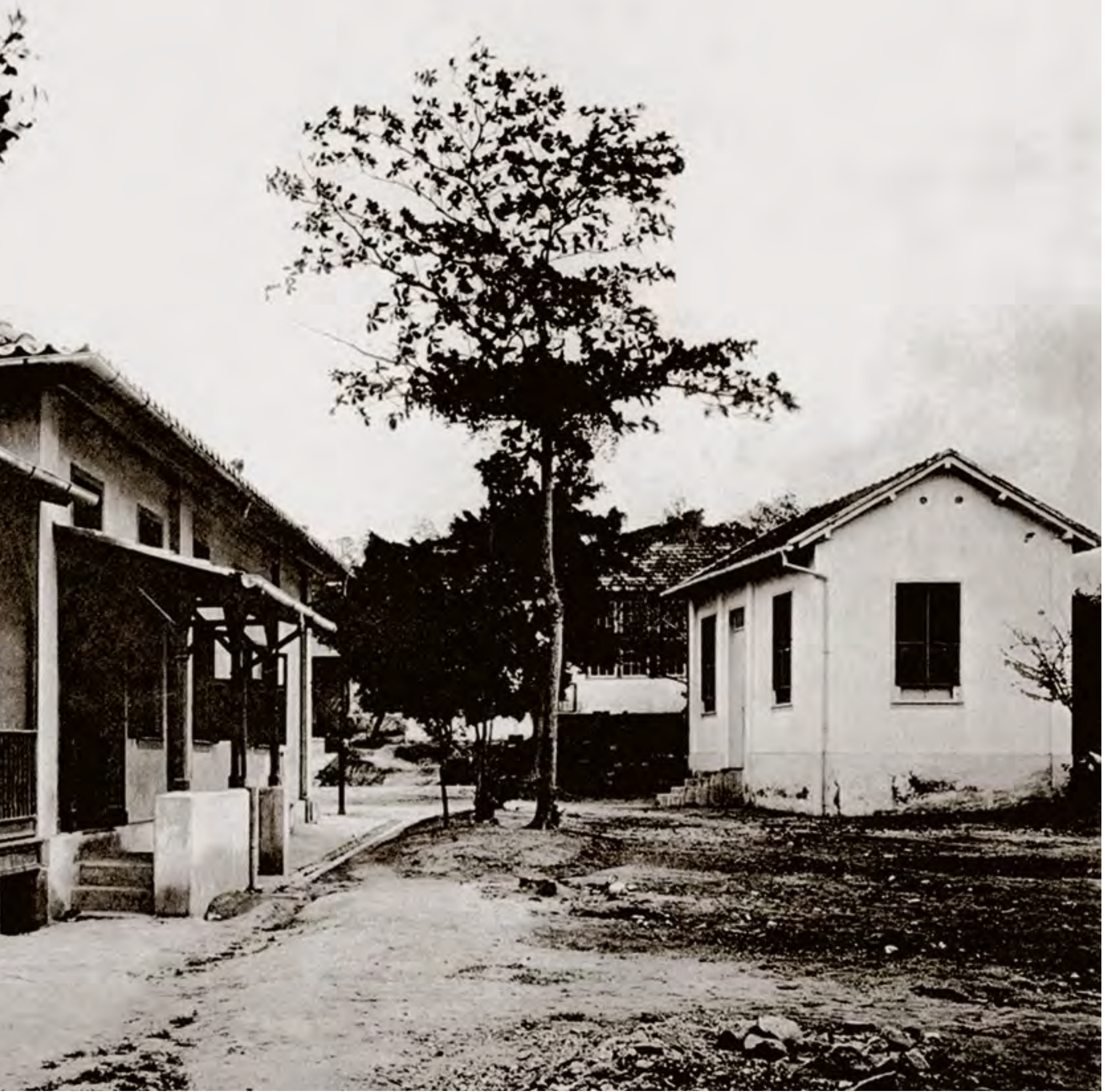

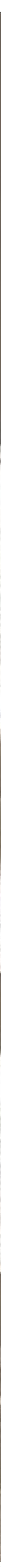

Sessão científica coordenada por Oswaldo Cruz no Instituto de

Manguinhos, 1904

De costas, Alcides Godoy. À sua direita: Antonio Cardoso Fontes,

Henrique da Rocha Lima, Oswaldo Cruz, Henrique Marques

Lisboa, Carlos Chagas, Ezequiel Dias, Rodolpho de Abreu Filho,

Paulo Parreiras Horta, Henrique Aragão e Afonso MacDowell

Acervo Casa de Oswaldo Cruz

Scientific session at the Manguinhos Institute, with Oswaldo

Cruz acting as coordinator, 1904. Facing away from the camera:

Alcides Godoy; to his right: Antonio Cardoso Fontes, Henrique da

Rocha Lima, Oswaldo Cruz, Henrique Marques Lisboa, Carlos

Chagas, Ezequiel Dias, Rodolpho de Abreu Filho, Paulo Parreiras

Horta, Henrique Aragão, and Afonso MacDowell 


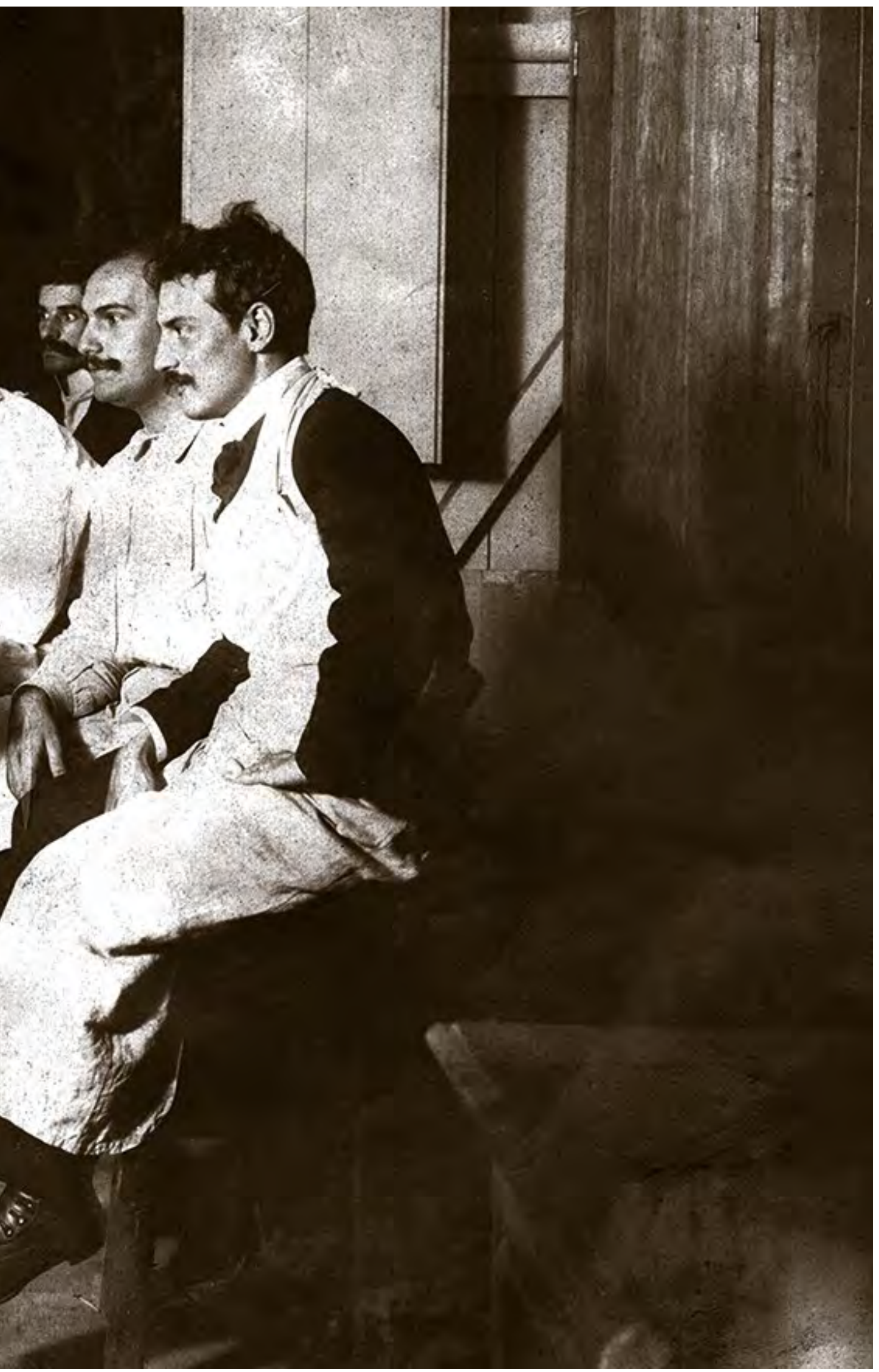

Tinha Oswaldo Cruz o trabalho de marcar, em cada revista, as publicações mais importantes assinalando o nome daquele que as deveria ler para resumi-las na sessão a realizar-se, semanalmente. $E$, neste mister, ia também orientando $o$ assunto conforme as tendências e predileções que observava em seus discípulos.

Henrique Aragão

It was Oswaldo Cruz's job to mark the more important articles in each journal and indicate the name of whomever should read and then summarize them at the weekly session. And in discharging this duty, he would also go about guiding the topic in accord with the inclinations and penchants he observed in his disciples. 


\section{Reise-Berichte}

über

Rinderpest, Bubonenpest in Indien und Alrika, Tsetse- oder Surrakrankheit, Texasfieber, tropische Malaria, Schwarzwasserlieber.

Von

Robert Koch.

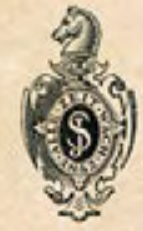

Berlin.

Verlag von Julius Springer. 1898.

\section{ETUDES}

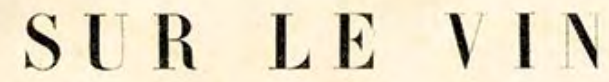

SES MALADIES

CAUSES QQU LES PROVOQUENT

PROCÉDÉS VOIVEAIX

POUR LE CONSERVR ET POUR LE VIEILLII

PAR M. L. PASTEUR

MEMeEE DK LINSTHYT

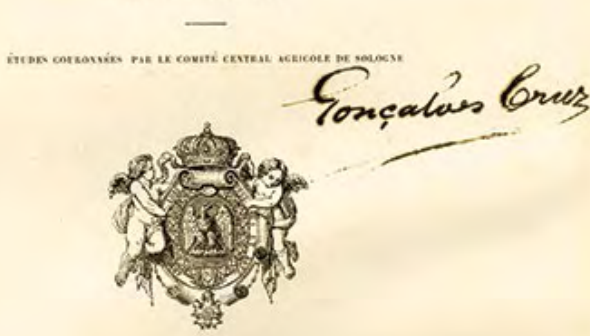

PARIS

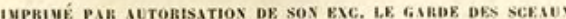

I L'IMPRIMERIE IMPÉRIALE

M DCCC: LVI
COURS DE MÉDECINE

DU COLLÉGE DE FRANCE

LECONS

$D E$

\section{PHISIOLOGIE OPÉRATOIRE}

\section{CLAUDE BERNARD}

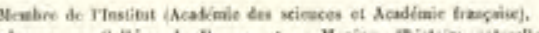

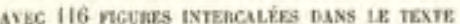

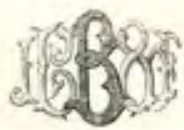

PARIS

LIBRAIRIE J.-B. BAILLIERE ET FII.S

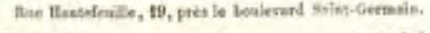

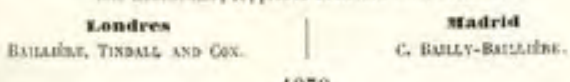

1879

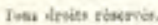

B.ATTISTA GRASSI

STUDI DI UNO ZOOLOGO

SULLA MALARIA

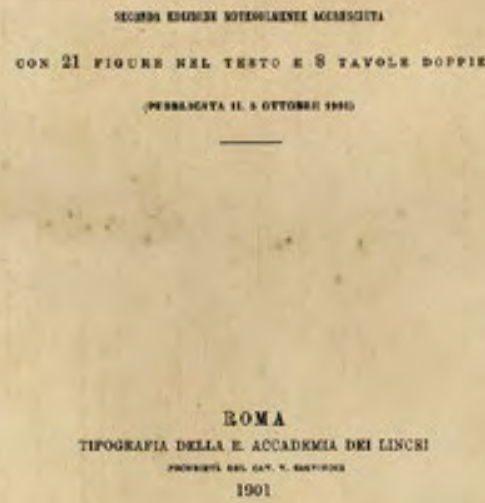




\title{
Tropical DISEASES
}

\author{
A Manual of the Diseases of Warm Climates
}

BY

\section{PATRICK MANSON C.M.G., M.D., LL.D. (ABERD.)}

Fellow of the Royal College of Physicians, London; Fellow of the Royal Society; Foreign Associate of the Académie de Médecine, France; Honorary

Member of the Société de Médecine de Sand: Physician to the Seamen's

Hospital Society; Lecturer on Tropical Diseases at St. George's

Hospital, Charing Cross Hospital Medical Schools; Lecturer in the London School of Tropical Medicine; Medical Adviser to the Colonial Office and to the Crown Agents for the Colonies
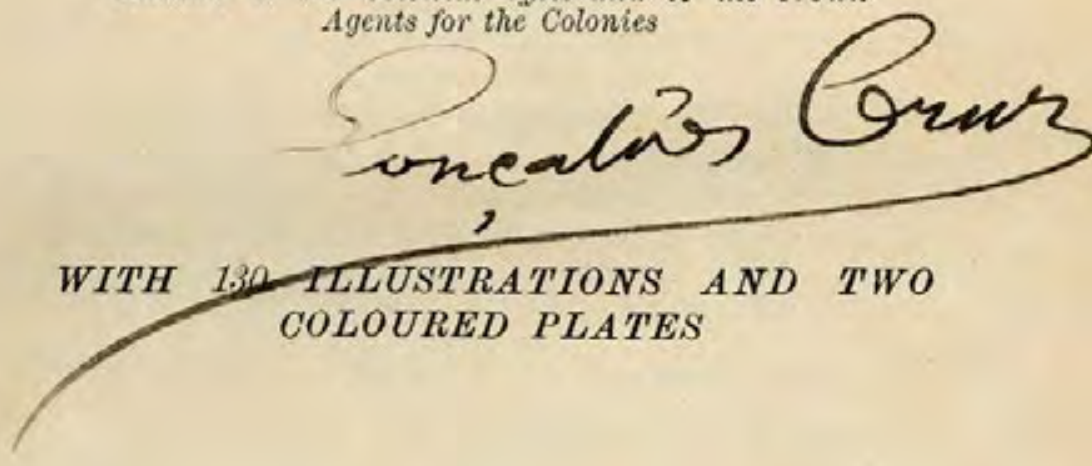

Riebised Edition

CASSELL AND COMPANY, Limited LONDON, PARIS, NEW YORK\& MELBOURNE. MCMIII

ALL RIGHTY RESERVED

Alguns dos principais autores no campo da medicina experimental. Livros

que pertenceram a Oswaldo Cruz e a Carlos Chagas

Acervo Casa de Oswaldo Cruz

Some of the main authors from the

field of experimental medicine. Books

that belonged to Oswaldo Cruz and

Carlos Chagas 


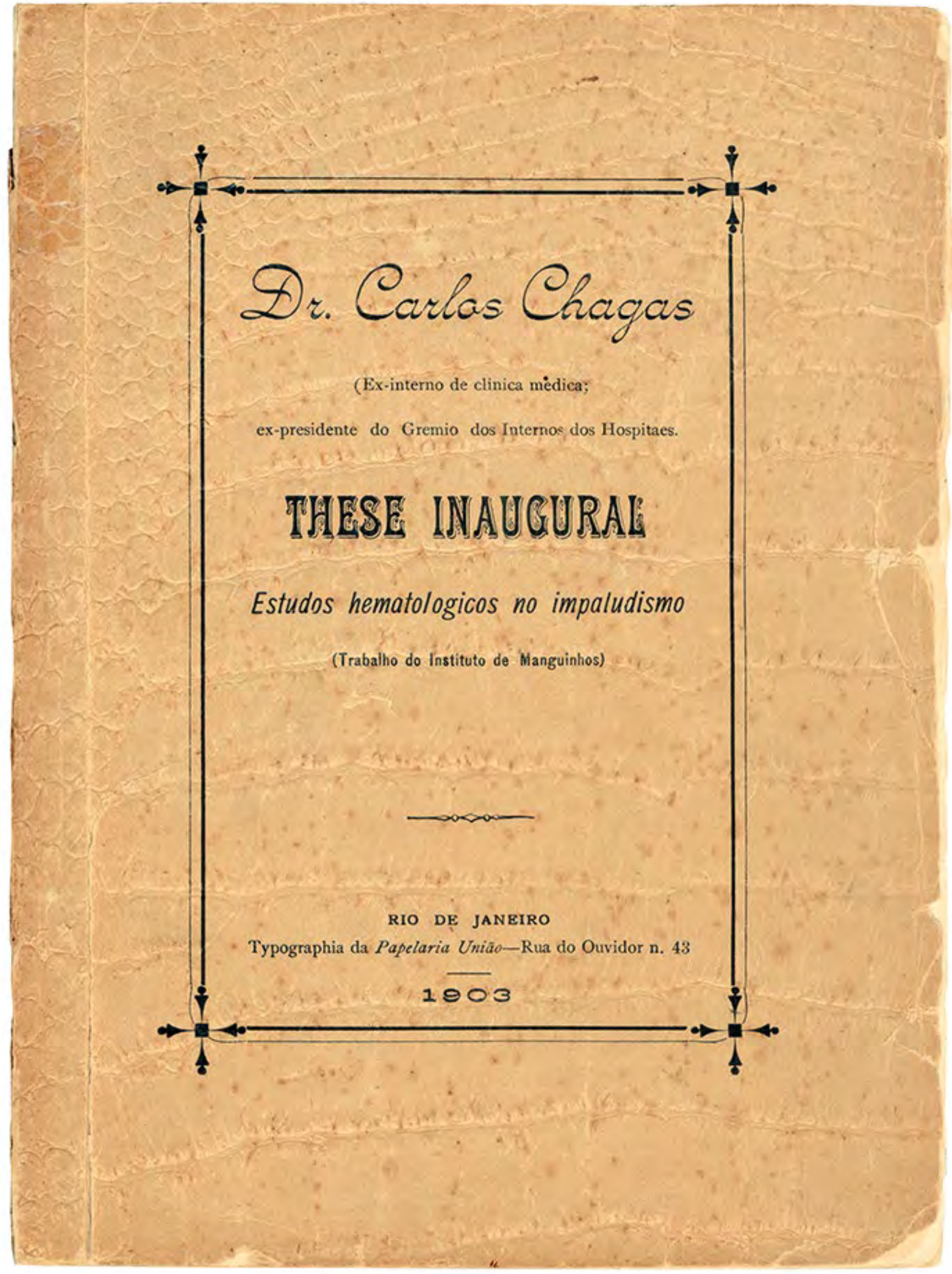

Tese de doutoramento na Faculdade de

Medicina. Rio de Janeiro, maio 1903

Acervo Casa de Oswaldo Cruz

Medical thesis. Rio de Janeiro, May 1903 


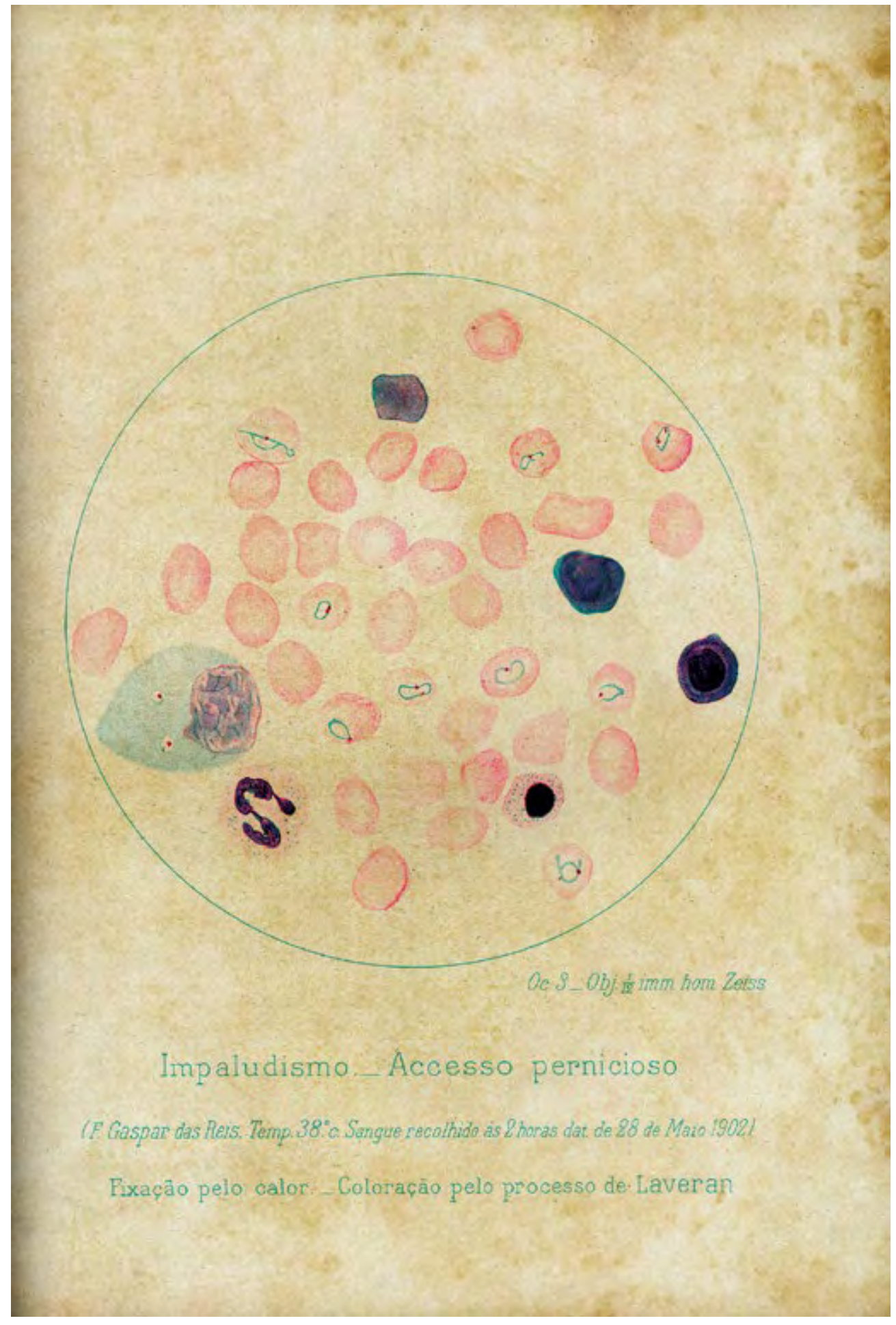

... o laboratório representa em nossa terra uma esperança.

Dele esperamos esclarecidos os inúmeros problemas de patologia tropical, que por aí prevalecem obscuros, zombando da sagacidade dos observadores e cujas incógnitas estão repletas das ilações as mais benéficas ao nosso bem-estar.

\section{Carlos Chagas}

(...) in our land, the laboratory represents hope. We hope it will clarify the countless issues in tropical pathology that still reign obscure among us, ridiculing the observer's wisdom, while these very unknowns abound with deductions that would greatly benefit our well-being.

Carlos Chagas

Preparação de sangue de um caso de malária. Figura publicada por Chagas em sua tese de doutoramento, em 1903 Acervo Casa de Oswaldo Cruz

Blood preparation from a malaria case.

Figure published by Chagas in his

medical thesis, in 1903 


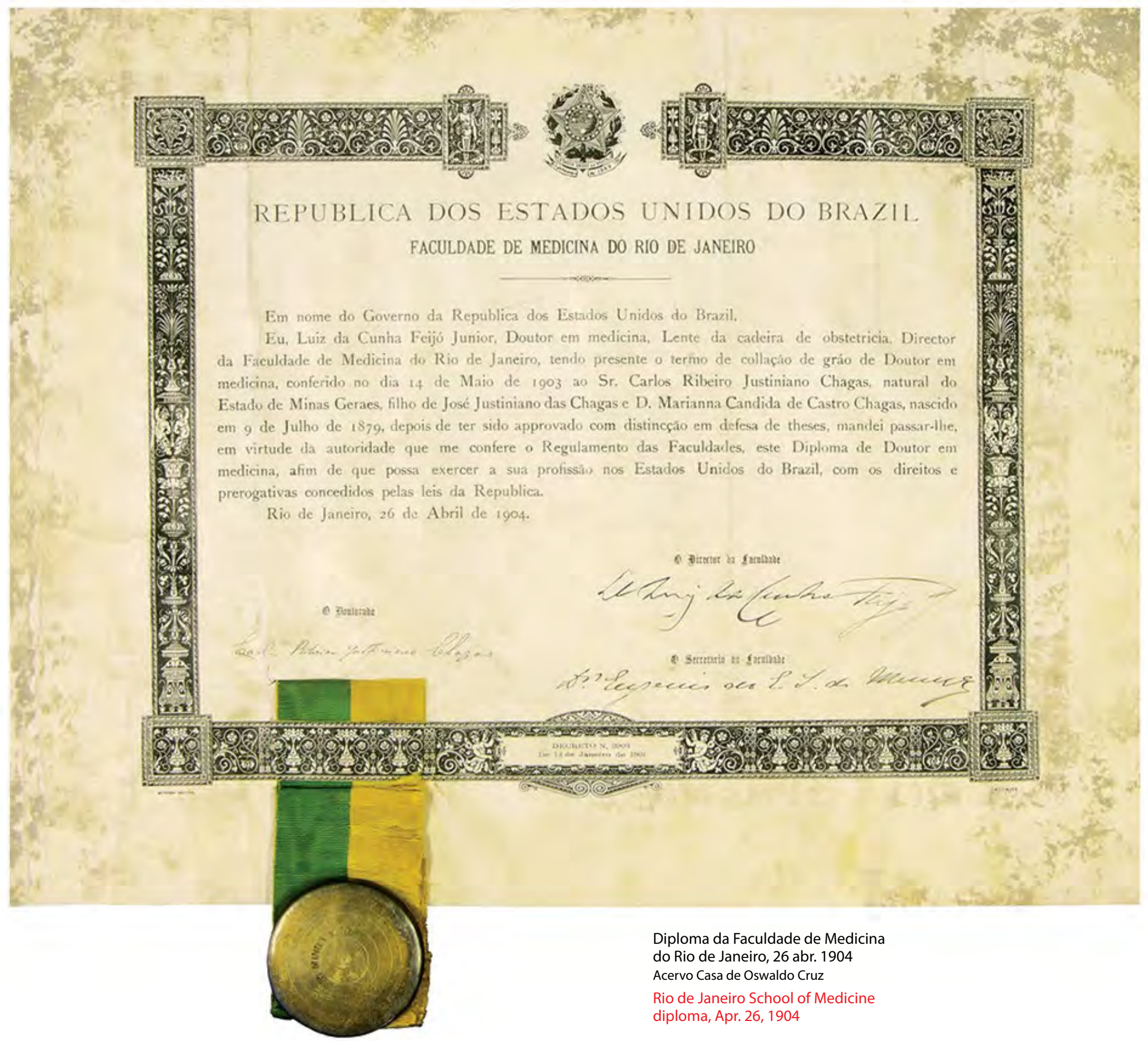




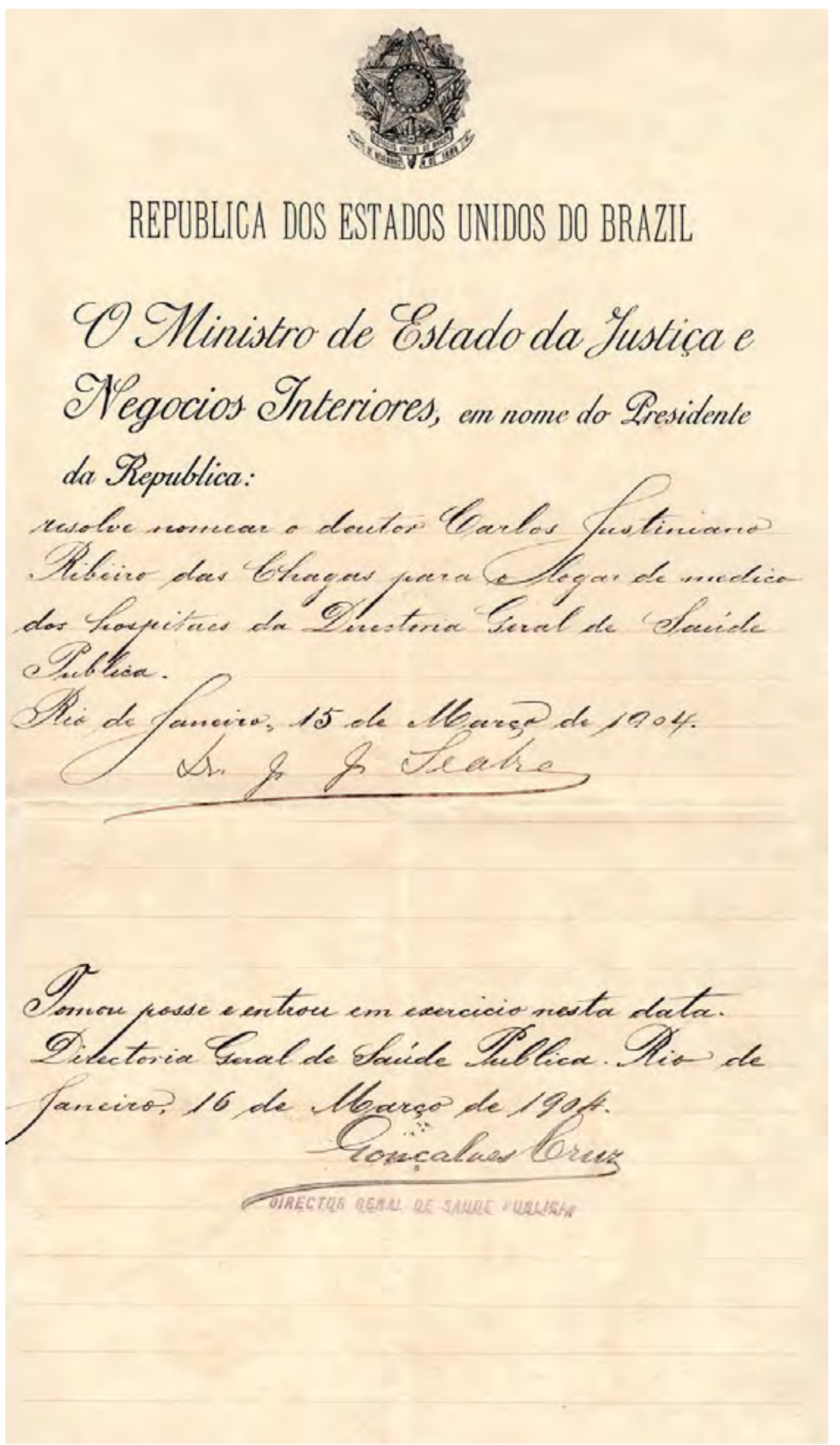

Nomeação para médico da Diretoria-Geral de Saúde Pública. Rio de Janeiro, 15 mar. 1904 Acervo Casa de Oswaldo Cruz

Official appointment as a physician with the General Directorship of Public Health. Rio de Janeiro, Mar. 15, 1904 


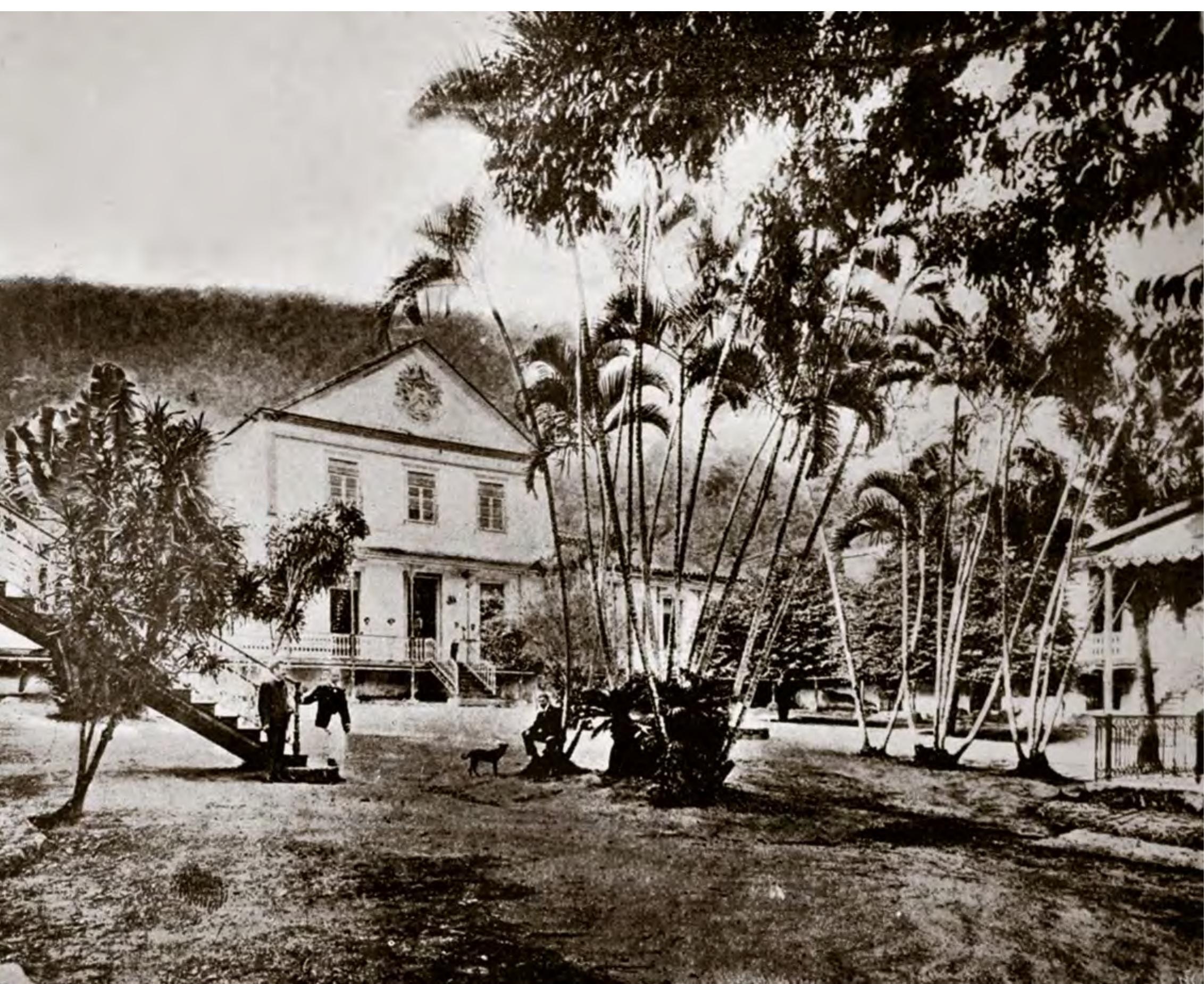

Hospital Paula Cândido, em Jurujuba, Niterói Fonte: Diretoria-Geral de Saúde Pública, 1909

Paula Cândido Hospital, in the neighborhood of Jurujuba, Niterói 

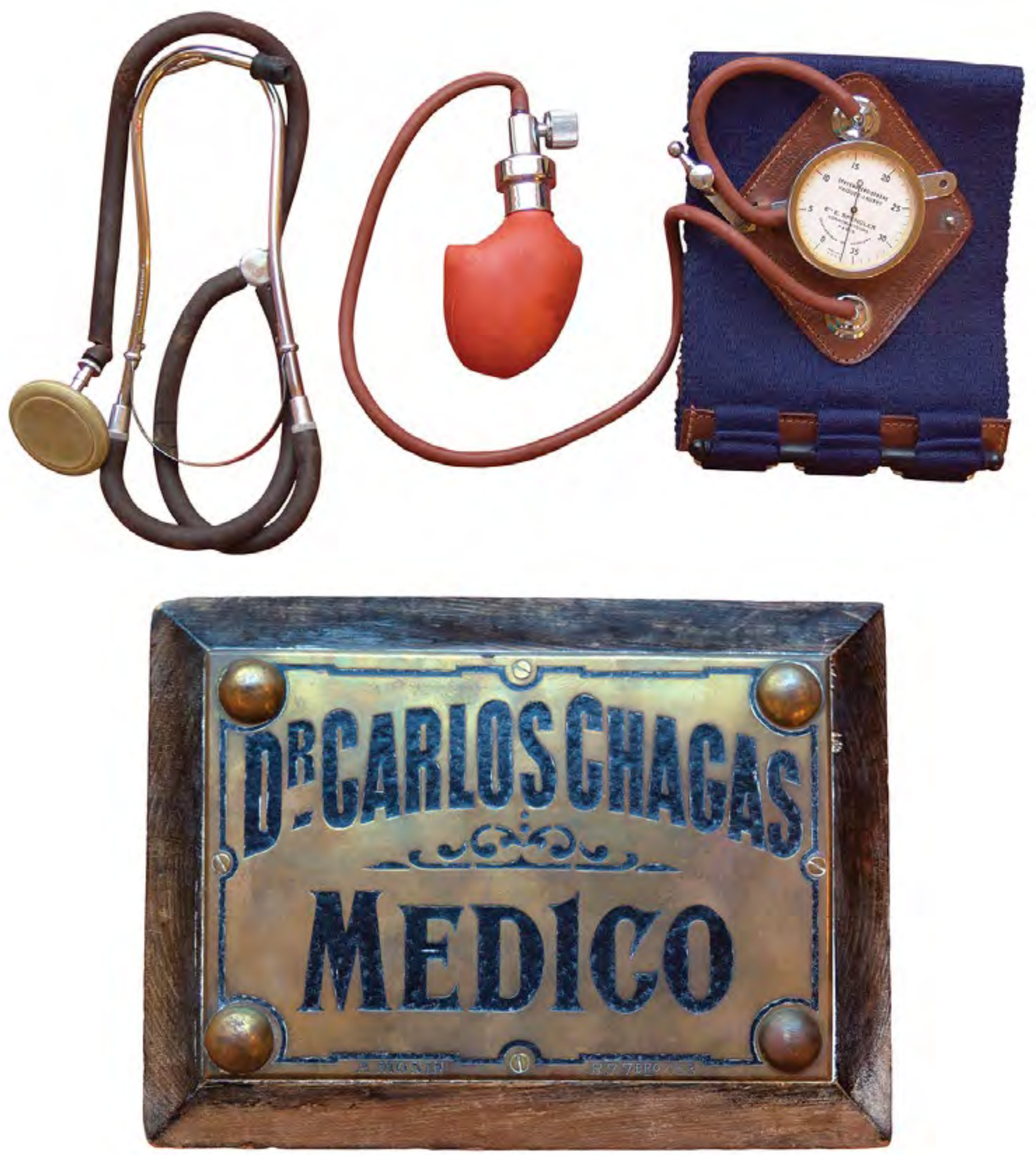

Estetoscópio e aparelho de pressão arterial que pertenceram

a Carlos Chagas

Acervo Casa de Oswaldo Cruz

Carlos Chagas's stethoscope and

blood pressure gauge

Placa de seu consultório médico,

instalado em 1904 na rua da

Assembléia, centro da cidade

do Rio de Janeiro

Acervo Casa de Oswaldo Cruz

Sign on Carlos Chagas's medical office

on Assembléia Street, downtown

Rio de Janeiro, established in 1904 